\title{
Correlation Between Students' Self-Efficacy and Breast Self-Examination (BSE) Practice in Nursing Students
}

\section{Dian Anggraini ${ }^{1}$ and Sri Wulan Gerhanawati ${ }^{2}$}

${ }^{1}$ Lecturer at Departemen of Nursing, Sekolah Tinggi Ilmu Keperawatan PPNI Bandung - West Java - Indonesia

${ }^{2}$ Nursing Student of Departemen of Nursing, Sekolah Tinggi IImu Keperawatan PPNI Bandung - West Java - Indonesia

ORCID:

Dian Anggraini: https://orcid.org/0000-0002-0428-0404

\section{Abstract}

Considering that breast cancer cases are increasing every year, it is important to promote early detection practices such as breast self-examination (BSE). Female students' ability to routinely perform a practice to prevent a disease may be affected

Corresponding Author:

Dian Anggraini

dians_23@yahoo.com

Published: 15 March 2021

Publishing services provided by

Knowledge E

(c) Dian Anggraini and Sri Wulan Gerhanawati. This article is distributed under the terms of the Creative Commons

Attribution License, which permits unrestricted use and redistribution provided that the original author and source are credited.

Selection and Peer-review under the responsibility of the IVCN Conference Committee.
S OPEN ACCESS by self-efficacy, their belief in their ability to produce an expected result that can affect their life. On the other hand, performing BSE will also promote students' self-efficacy. The present study aims to find out the correlation between self-efficacy and BSE practices amongst female students of STIKep PPNI West Java. This study employed non-experimental quantitative methods, adapted from Champion's Health Belief Model Scale (CHBMS). The results showed that there was a significant correlation between students' self-efficacy and breast self-examination practice on female students of STIKep PPNI West Java. This indicates that self-efficacy is important to changed behaviour. The findings are expected to improve female students' awareness to perform breast self-examination (BSE) practice since their adolescence years.

Keywords: breast_self_examination, practice, self_efficacy

\section{Introduction}

Cancer is a non-contagious disease that belongs to general health problems category. The 2018 Global Cancer Observatory data from World Health Organization (WHO) indicated that 58,256 cases $(16.7 \%)$ of 348,809 cancer cases were breast cancer. Breast cancer is also the number one cause of death in females. The 2019 Basic Health Research in Indonesia showed that the greatest prevalence of breast cancer in the country was 42.1 per 100,000 people, with the average rate of mortality of 17 per 100,000 people. It was estimated that 6.701 cases occurred in West Java.

Breast self-examination (BSE) is a practice of early detection for breast cancer, which makes it highly useful for finding breast cancer symptoms since the early stages so that 
it can be treated as early as possible (Savitri, et al., 2015). According to the 2016 NonContagious Disease Research, only a very small percentage of women performs BSE (25-30\%). The same research also noted that $53.7 \%$ of female population in Indonesia never performed BSE at all. This indicates that Indonesian women are still not aware of the importance of early detection of breast cancer. Routine monthly BSE practice can be performed since the age of 20 to detect any anomaly on the breasts as early as possible so that it can be treated properly (Savitri, et al., 2015).

Among the members of this age group are female students, which means that they should start performing BSE regularly. Female students can be defined as female individuals who are studying at university level, in both state and public universities or other institutions of the same level. Female students are considered to be highly intellectual, intelligent, and able to plan their actions. Critical thinking and quick response are characteristics usually embedded in these students (Siswoyo, 2007).

Students' ability to routinely perform a practice of early disease detection is affected by self-efficacy, which is an individual's belief in their ability to produce an expected result that can affect their life. Self-efficacy is the basis for their motivation, welfare, and achievement because self-efficacy determines how the individual feel, think, motivate themselves, and act (Bandura, 2004). High level of self-efficacy has to do with immune system because those beliefs will affect one's attempts to maintain their health and to prevent diseases. This indicates that self-efficacy is important in determining whether or not an individual believes and is able to achieve the expected changes in behaviors. Self-efficacy will improve female students' confidence, after performing BSE, in improving and maintaining the quality of their life.

A study by Putri (2017) showed that self-efficacy had a correlation with breast selfexamination (BSE) practice on women in Tegalrejo Sub-district, Yogyakarta City. A previous study that supported this was Mediana Virgin's (2019). Her study focused on "Self-efficacy in Breast Self-Examination (BSE) Practice on Female Students of STIKep PPNI West Java" and found that the respondents (83 female students of STIKep PPNI West Java) had sufficient level of self-efficacy.

Interviews with 12 female students of STIKep PPNI West Java indicated that most of them were aware of breast self-examination (BSE) practice from their lessons in the fifth semester (third year). Nine of the 12 respondents stated that they had tried BSE. Four of them stated that they routinely performed BSE and were confident that they could do it properly, while the remaining five believed that they could perform BSE properly even though they did not do it regularly. The other three students being interviewed claimed 
that they never performed BSE because they were not confident that they were able to do it properly even though they had had lessons on that topic.

Female students in STIKep PPNI West Java have learned about various diseases and their prevention efforts, including breast cancer and breast self-examination (BSE). Breast self-examination (BSE) is a disease prevention practice that is tested in Maternity subject at the end of the fifth semester at STIKep PPNI West Java. BSE is taught to make female students understand and able to perform it in their daily life as prevention, promotion, and protection from breast cancer. Including BSE in the final exam of Maternity subject is expected to develop self-efficacy in the students to perform BSE regularly. This topic interests the researcher to examine the "Correlation between Students' Self-Efficacy and Breast Self-Examination (BSE) Practice on Female Students of STIKep PPNI West Java".

\section{Method}

The present study was a non-experimental study using quantitative method. The sampling technique was total sampling, consist 154 female students (bachelor degree) from third- and fourth-year. This study utilized self-efficacy and breast self-examination (BSE) questionnaire which had been adapted and modified to suit the Standard Operational Procedure for measuring BSE practice. Self-efficacy questionnaire was modified from Putri, et. al. (2017), who had adapted Champion's Health Belief Model Scale (CHBMS) and translated it into Bahasa Indonesia. Meanwhile, breast self-examination questionnaire was adapted from the BSE Standard Operational Procedure utilized by Yusrah Taqiyah (2020). This questionnaire consisted of 45 questions, in which 16 items were self-efficacy questions and 29 items were BSE SOP. The questionnaire was validated by three experts for Content Validity Index. The average validity score for all items was 0.938 . Aiken's $V$ coefficient was in the range of $0-1$. Since the $V$ coefficient of the questionnaire was 0.917 , the questionnaire was deemed valid.

Data was collected using google form link (https://docs.google.com/forms/d/e/ 1FAIpQLSc1rzoziAut71sMJZshfG_ixlkqKkrVY4BKwDyl6UznxcpnQ/viewform) provided for the students. Univariate analysis was conducted to measure the mean, median, standard deviation, minimum, maximum, and reliability scores of the variables. Bivariate analysis was conducted using Pearson's Correlation test to discover the correlation between self-efficacy and BSE practice. 


\section{Results of Analysis}

\subsection{Univariate Analysis}

TABLE 1: Respondents' Characteristics

Variable
Age
20
21
22
23
Past experience
Have
Do not have
Family experience
Have
Do not have
Experience of the closest person
Have
Do not have

\begin{tabular}{|c|}
\hline $\mathbf{n}$ \\
\hline 47 \\
\hline 63 \\
34 \\
10 \\
\hline 4 \\
\hline 150 \\
\hline 4 \\
\hline 150 \\
\hline 140 \\
\hline 14
\end{tabular}

\begin{tabular}{|c|}
\hline$\%$ \\
\hline 30.5 \\
\hline 40.9 \\
\hline 22.1 \\
\hline 6.5 \\
\hline 2.6 \\
\hline 97.4 \\
\hline 97.4 \\
\hline 2.6 \\
\hline 90.9 \\
\hline 9.1
\end{tabular}

Based on Table 1, respondents' age was in the range of vulnerable age group, i.e. 20 to 23 years old. Almost all respondents did not have any personal experience, family experience, or close acquaintances' experience of breast cancer.

TABLE 2: Self-Efficacy and Breast Self-Examination Scores

Variable
Self Efficacy
Self-Breast Examination

Mean \pm SD
$50.40 \pm 5.170$
$36.19 \pm 5.940$

\begin{tabular}{|c|}
\hline Range \\
$\begin{array}{c}16-64 \\
0-45\end{array}$ \\
\hline
\end{tabular}

Table 2 shows that the average score of self-efficacy was 50.40 (SD $=5.170$ ), while the average highest score of breast self-examination $36.19(\mathrm{SD}=5.940)$.

\subsection{Bivariate Analysis Result}

Variables in this study were tested using Pearson's correlation to find out whether there was a correlation between self-efficacy and breast self-examination on female students of STIKep PPNI West Java. The results of Pearson's correlation analysis could be seen in Table 3. 
TABLE 3: Correlation between Self-Efficacy and Breast Self-Examination Practice at STIKep PPNI West Java $(n=154)$

\begin{tabular}{|l|l|c|c|}
\hline & & Self Efficacy & $\begin{array}{c}\text { Self-Breast } \\
\text { Examination } \\
\text { (BSE) }\end{array}$ \\
\hline Self Efficacy & Pearson Correlation & & 0.223 \\
& Sig. (2-Tailed) & 1 & 0.005 \\
\hline Self-Breast Examination (BSE) & N & & 154 \\
& Pearson Correlation & 154 & 1 \\
\hline & Sig. (2-Tailed) & 0.223 & \\
\hline & $N$ & 0.005 & 154 \\
\hline
\end{tabular}

Table 3 indicates that the correlation between the two variables was 0.223 . If the significance score was exactly 0.05 , the Pearson correlation should be compared to

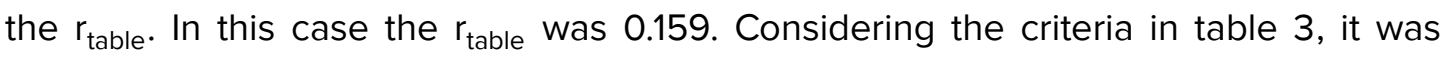
concluded that there was a significant correlation between self-efficacy and breast selfexamination on female students of STIKep PPNI West Java because the significance score was $0.223>0.159$. However, the correlation was weak because it was in the range of 0.21 to 0.40 .

\section{Discussion}

Based on the findings of this study, there was a correlation between self-efficacy and breast self-examination on female students of STIKep PPNI West Java, with p-value $(0.223)>d r_{\text {table }}(0.159)$. The correlation was affected by age, performance accomplishment; which consisted of knowledge, past experiences, and ability to act; and vicarious experiences, including experiences of family members and close acquaintances. The findings of this study were not entirely in line with Susilowati's study (2016). Susilowati (2016) had found that there were four cognitive theories affecting women's self-efficacy in performing BSE. The present study found that social persuasion, which consisted of social support and health information, and physiological and emotional state, which consisted of family income, mood, and negative emotion, did not affect the correlation between self-efficacy and BSE practice.

The respondents of this study were in the age group of 20-23 years old. This age group was considered the most appropriate age to perform BSE regularly every month to detect breast anomaly as early as possible so that it could be treated properly. Furthermore, Sjamsuhidajat and Wim (2005) argued that in this age group, ducts might have 
developed and asinus had emerged due to the effects of estrogen and progesterone hormones produced by ovarium and hypophyse hormone since the puberty.

Female students in STIKep PPNI West Java have learned about various diseases and their prevention efforts, including breast cancer and breast self-examination (BSE). This knowledge had to do with good self-efficacy, and respondents with low risk of breast cancer possessed good skills of performing BSE (Susilowati, 2016).

As the students age, their experiences grow through their learnings in organizations or in life. These experiences were grouped into past personal experiences, family members' experiences, and close acquaintances' experiences (Table 1). Based on the data in Table 1, female students of STIKep PPNI did not have any experiences of breast cancer but they had high level of self-efficacy. This finding was in line with Susilowati's findings (2016), in which her female respondents had low risks of breast cancer and did not have any experiences of breast cancer, both in their family and in their close acquaintances. Susilowati (2016) also found that the respondents had good self-efficacy to perform BSE.

Female students' ability to perform breast self-examination as a form of breast cancer prevention might be affected by self-efficacy. Students' ability to routinely perform a practice of disease prevention might be affected by self-efficacy, i.e. an individual's belief of their own ability to produce an expected result that can affect their life. Selfefficacy is the basis for their motivation, welfare, and achievement because self-efficacy determines how the individual feel, think, motivate themselves, and act. This was supported by Green (1980), who stated that predisposition was a factor that facilitated a behavior. Predisposition included knowledge, attitude, cultural values, perception, and individual characteristics such as age, sex, educational background, and profession. Considering this, respondents in the present study, who were students of medical discipline, should be able to develop their motivation and self-efficacy to perform breast self-examination.

\section{Conclusion}

There was a significant correlation between self-efficacy and breast self-examination practice on female students of STIKep PPNI West Java. 


\section{References}

[1] Bandura, A. (1997). Self Efficacy. The Exercise of a Control. New York: W. H Freeman and Company.

[2] Bandura, A. (1986). Social Foundations of Thought and Action. New Jersey: Prentice Hall.

[3] Bandura, A. (2004). Self Efficacy: In Changing Sacietoes. United Kingdom: Cambridge University Pres.

[4] Harnianti., Sakka, A., \& Saptaputra S.K. (2016). Studi Perilaku Pemeriksaan Payudara Sendiri (SADARI) pada Mahasiswi Fakultas Kesehatan Masyarakat Universitas Halu Oleo Tahun 2016. [Skripsi IImiah]. Kendari: Fakultas Kesehatan Masyarakat Universitas Halu Oleo

[5] Hastuti, R. Y. (2010). Correlation between Knowledge Level about Breast Cancer and Breast Cancer Early Detection Behavior in Women of Fertile Age in Mojodoyong Village, Kedawung, Sragen.

6] Kemenkes RI. (2015). Data dan Information Center. Jakarta Selatan: Indonesian Ministry of Health.

[6] Khiyali, Z., et al. (2017). Educational Intervention on Breast Self-Examination Behavior in Women Referred to Health Centers: Application of Health Belief Model. Asian Pacific Journal of Cancer Prevention. Page 2833-2838.

[7] Kusumaningrum, T. A. S. (2018). Application of Health Belief Model on Public Health Student Behavior in Self-Breast Examination (BSE). Surakarta: Faculty of Health Sciences, Muhammadiyah University of Surakarta.

[8] Lestari, P. W. (2019). The Importance of Self-Breast Examination (BSE) as an Effort to Detect Breast Cancer Early. Indonesian Journal of Community Empowerment (IJCE).

[9] Lestari, P. I. (2018). The Effect of Health Education Demonstration Method About BSE on the Ability to do BSE on Teenage Girls in Diponegoro Dampit High School. (Thesis for a Bachelor's Degree in Midwifery, Health Polytechnic of the Ministry of Health, 2018).

[10] Nurliana and Salmiyati, S. (2018). The Influence of Health Education with the Demonstration Method of Awareness of BSE Attitudes in Productive Age Women in Pengkol Kulon Progo Hamlet.

[11] Olfah, Y., Mendri, N. K. and Badi'ah, A. (2013). Breast Cancer \& BSE. Yogyakarta: Nuha Medika.

[12] Purwoastuti, T. E. (2008). Breast Cancer. Yogyakarta: Kanisius. 
[13] Putri, D. I. (2015). Description of Self-Breast Examination Behavior (BSE) in Students of the Faculty of Medicine and Health Sciences UIN Syarif Hidayatullah Jakarta in 2015. (Bachelor Thesis, UIN Syarif Hidayatullah Jakarta, 2015).

[14] Putri, I. M. (2017). The Relationship between Self Efficacy and Self-Breast Checking Behavior (BSE) in Women in Tegalrejo District, Yogyakarta City. (Bachelor Thesis Aisyiyah University Yogyakarta, 2017).

[15] Rasjidi, I. (2009). Early Detection \& Prevention of Cancer in Women. Jakarta: Sagung Seto.

[16] Riset Kesehatan Dasar. (2013). Ministry of Health Research and Development Agency of the Republic of Indonesia in 2013.

[17] Savitri, A., Alina, L. and Utami, E. D. R. (2015). Thoroughly Peel Breast, Cervical and Uterine Cancer. Yogyakarta: New Library Press.

[18] Sjamsuhidajat, R. and Jong, D. (Eds.). (2005). Surgical Textbook. Jakarta: EGC.

[19] Susilowati, W. and Qomaruddin, M. B. (2016). Self Efficacy of Women Age 35-44 Years in Efforts to Prevent Breast Cancer. Journal.

[20] Taqiyah, Y. and Jama, F. (2020). Awareness Training (Self-Breast Examination) as an Effort to Detect Breast Cancer Early in Baznas Health Vocational School Students. Indonesian Journal of Community Dedication (IJCD).

[21] Virgin, M. (2019). Self Efficacy Overview of Self-Examination of Breast (BSE) in West Java PPNI STIKep Students. (Bachelor Thesis, West Java PPNI College of Nursing, 2019). 